\title{
Trace elements and oxidative stress in children with type I diabetes mellitus
}

This article was published in the following Dove Press journal: Diabetes, Metabolic Syndrome and Obesity:Targets and Therapy

\author{
Ashgan Abdalla Alghobashy' \\ Usama MAlkholy' \\ Mohamed A Talat' \\ Nermin Abdalmonem' \\ Ahmed Zaki \\ Ihab A Ahmed' \\ Randa H Mohamed ${ }^{3}$ \\ 'Department of Pediatrics, Faculty \\ of Medicine, Zagazig University, \\ Zagazig, Egypt; ${ }^{2}$ Department of \\ Pediatrics, Faculty of Medicine, \\ Mansura University, Mansura, Egypt; \\ ${ }^{3}$ Department of Biochemistry, Faculty \\ of Medicine, Zagazig University, \\ Zagazig, Egypt
}

Background: The early imbalances of trace elements in type 1 diabetes (T1D) may cause disturbance of glucose metabolism and more oxidative stress that may enhance the development of insulin resistance and diabetic complications. We aim to evaluate the serum level of selenium $(\mathrm{Se})$, zinc $(\mathrm{Zn})$, magnesium $(\mathrm{Mg})$, and copper $(\mathrm{Cu})$, the degree of oxidative stress and evaluate their relations to glycemic control in children with T1D.

Methods: A case-control study which included 100 diabetic children and 40 healthy children age, sex, and ethnicity-matched as a control group. The diabetic children were divided into poor and good controlled patients according to glycosylated hemoglobin (A1c \%). Studied children underwent history taking, clinical examination and laboratory measurement of serum $\mathrm{Se}, \mathrm{Zn}, \mathrm{Mg}$, and $\mathrm{Cu}$ levels, erythrocyte reduced glutathione (GSH) and peroxidase enzyme activity (GPx). Results: Serum $\mathrm{Se}, \mathrm{Zn}, \mathrm{Mg}, \mathrm{Cu}$, erythrocyte GSH, and GPx were significantly lower in the diabetic group in comparison to the control group $(P<0.05)$ and their levels were lower in poorly controlled patients compared to good controlled patients $(P<0.05)$. The serum $\mathrm{Se}, \mathrm{Zn}, \mathrm{Mg}$, erythrocyte GSH, and GPx showed a negative correlation with A1c \%. The serum Se showed a positive correlation with erythrocyte GSH and GPx ([r=0.56, $P<0.001],[\mathrm{r}=0.78, P<0.001]$, respectively).

Conclusion: Children with T1D, especially poorly controlled cases, had low serum Se, Zn, $\mathrm{Mg}, \mathrm{Cu}, \mathrm{GSH}$, and GPx. Low serum Se in diabetic children may affect the erythrocyte GSHGPx system.

Keywords: oxidative stress; type 1diabetes; trace elements, reduced glutathione, peroxidase

\section{Introduction}

Diabetes mellitus (DM) is a metabolic disorder of impaired glucose metabolism. Poor glycemic control in type 1 diabetes (T1D) usually leads to more oxidative stress, increased production of oxygen-free radicals and more diabetic complications. The trace elements like selenium $(\mathrm{Se})$, zinc $(\mathrm{Zn})$, and copper $(\mathrm{Cu})$ are involved in the process of lipid peroxidation and play an important role in the pathogenesis and exacerbation of diabetic complications. ${ }^{1} \mathrm{Zn}$ is very important for glucose metabolism and plays a key role in the synthesis, storage, and secretion of insulin. ${ }^{2}$ Magnesium $(\mathrm{Mg})$ is important for glucose metabolism and its deficiency has been implicated in insulin resistance, carbohydrate intolerance, dyslipidemia and complications of diabetes. ${ }^{3}$ Se has an antioxidant effect and plays an important role in the protection against oxygen free radicals. ${ }^{4}$ Se enters in the structure of selenocysteine which is an important part of the structure of several glutathione peroxidases (GSH-GPx) present in different tissues. Reduced glutathione
Correspondence: Usama M Alkholy Department of Pediatrics, Zagazig University, PO Box 7500, Jeddah 21462 , Saudi Arabia

Tel +966550491948

Fax +96 6I 26939500

Email usamaalkoly@yahoo.com 
(GSH) is considered as the most important antioxidant that prevents oxidative damage of the cell membrane by free radicals. ${ }^{5}$ Elevated serum $\mathrm{Cu}$ level in diabetic children has been reported before to be associated with macroangiopathy, hypercholesterolemia, and hypertension. However, $\mathrm{Cu}$ deficiency might be a contributor to the glucose intolerance in T1D. ${ }^{6} \mathrm{Zn}$ and $\mathrm{Cu}$ are considered the most important cofactors for the action of superoxide dismutase antioxidant. ${ }^{7}$ The aim of our study was to evaluate the serum level of trace elements $\mathrm{Mg}, \mathrm{Se}, \mathrm{Zn}$, and $\mathrm{Cu}$, assess the degree of oxidative stress and evaluate their relations to glycemic control in children with T1D.

\section{Subjects and methods}

This case-control study was conducted at Zagazig Pediatric Endocrinology Outpatient Clinic during the period from March 2016 to December 2016. Subjects were divided into a Diabetic group which included 100 children with T1D who were all confirmed serologically based on autoantibody positivity, and a Control group which included 40 healthy children who were age, sex, and ethnicity-matched and who were not suffering from any chronic illness, not taking any medication and came for mild acute illness to outpatient clinics. Patients with T1D were divided into two groups according to glycosylated hemoglobin (A1c \%) into 75 poorly controlled patients with A1c $\% \geq 7.5$ and 25 good controlled patients with A1c $\%<7.5$. Written informed consent was obtained from the children's guardians and approval was provided by the local ethical committee in our Zagazig University Hospital.

The inclusion criteria were for diabetic cases aged 1-18 years, with good nutritional history and were under follow up at the outpatient clinic of the Pediatric Endocrinology Unit, Zagazig University Hospital.

The exclusion criteria were for diabetic children with complications such as retinopathy or nephropathy, with chronic diseases such as renal disorder or Wilson disease, cases with supplemental intake of $\mathrm{Se}, \mathrm{Zn}, \mathrm{Mg}$, and $\mathrm{Cu}$ in the last 6 months and cases who had received total parenteral nutrition or antioxidants in the last month.

All the subjects underwent the following:

- History taking to evaluate age at onset, duration of the disease, type, and dose of insulin and full clinical examination with measurement of height, weight, and BMI.

- Laboratory investigations:

- After overnight fasting, $2 \mathrm{~mL}$ venous blood samples were taken from the patients then the serum part was preserved in an Eppendorf tube at $-20^{\circ} \mathrm{C}$ for measurement of serum levels of $\mathrm{Se}, \mathrm{Zn}, \mathrm{Mg}$, and $\mathrm{Cu}$ while the erythrocyte part was washed in isotonic saline, hemolysis was carried out by adding cold distilled water and then centrifuged at $2000 \times g$ for 15 minutes to remove any cellular debris. The hemolysate was used for assessment of erythrocyte GSH and GPx levels.

- Serum $\mathrm{Zn}, \mathrm{Mg}$, and $\mathrm{Cu}$ levels were measured by the direct colorimetric method and serum Se was measured with Electro-Thermal Atomic Absorption Spectrometry. ${ }^{8}$

- Serum Zn present in the sample is chelated by zincon (2-carboxy-2-hydroxy-5-sulfoformazyl-benzene) in the reagent at alkaline $\mathrm{pH}$. The formation of this complex is measured at a wavelength of $610 \mathrm{~nm}$. Normal value: $0.7-1.1 \mathrm{mmol} / \mathrm{L}(1.70-2.70 \mathrm{mg} / \mathrm{dL}){ }^{9}$

- Serum $\mathrm{Cu}$ is released from protein by hydrochloric acid. The protein is precipitated by trichloroacetic acid, Di ethyldi thio carbamate forming a golden yellow-colored complex with copper which can be extracted by n-butanol. The formation of this complex is measured at a wavelength of $440 \mathrm{~nm}$. Reference ranges: $12-25 \mu \mathrm{mol} / \mathrm{L}^{10}$

- Mg ions react in an alkaline medium with the metallochrome dye calmagite to form a chromophore which absorbs at $520 \mathrm{~nm}$. Calcium is excluded from the reaction by complexing with ethylene glycol bis ( $\beta$-aminomethyl ether)-N,N, $\mathrm{N}^{\prime}, \mathrm{N}^{\prime}$-tetracetic acid (EGTA). The formation of this complex is measured at a wavelength of $610 \mathrm{~nm}$. The normal value is $0.7-1.1$ mmol/L. ${ }^{11}$

- Erythrocyte glutathione peroxidase (GPx) activity was measured by commercial Ransel kits (Randox Laboratories, Crumlin, Northern Ireland, UK) ${ }^{12}$ and erythrocyte reduced glutathione (GSH) levels were measured by the method described by Beutler et al. ${ }^{13}$

- Measurement of A1c \% by Cobas Integra 6000 (Hoffman-LaRoche Ltd., Basel, Switzerland).

- Routine laboratory measurement of fasting plasma glucose (FPG), fasting triglycerides and total cholesterol.

\section{Statistical analysis}

Data were checked, entered, and analyzed using SPSS version 20. Data were expressed as number and percentage for qualitative variables and mean $\pm \mathrm{SD}$ for quantitative ones. The Student's $t$-test was used for comparison of means of two independent groups. The Chi-square test was used to find 
the association between row and column variables. Pearson correlation coefficient was used to calculate the correlation between quantitative variables. The level of significance was considered positive if the $P$-value $<0.05$.

\section{Results}

Our sample of study included 100 children with T1D with a mean age of $11.6 \pm 2.9,50 \%$ males and $50 \%$ females and their BMI was $18.5 \pm 1.7$ compared to 40 healthy children as a control group with a mean age of $11.4 \pm 2.8,45 \%$ males and $55 \%$ females and their BMI $18.6 \pm 0.7$. The duration of illness of the diabetic group ranged from 1 to 11 years while the mean age was 4.8 years, the insulin dose ranged from 0.5 to $1.5 \mathrm{unit} / \mathrm{kg}, 45 \%$ of the patients used basal bolus and $45 \%$ were on 3 times per day blood glucose monitoring. No significant differences were found between both groups in age, sex, BMI, triglycerides, and total cholesterol. The FPG was statistically significantly higher in diabetic patients when compared to the control group (Table 1).

Serum $\mathrm{Se}, \mathrm{Cu}$, erythrocyte GSH, and GPx were highly statistically significantly lower in the diabetic group when compared to the control group $(P<0.001)$. Serum $\mathrm{Zn}$ and $\mathrm{Mg}$ were statistically significantly lower in the diabetic group when compared to the control group $(P<0.05)$. The A1c \% was statistically significantly higher in the diabetic group when compared to the control group $(P<0.001)$ (Table 2$)$.

Serum $\mathrm{Se}, \mathrm{Zn}, \mathrm{Mg}, \mathrm{Cu}$, erythrocyte GSH, and GPx were highly statistically significantly lower in the poorly controlled patients when compared to the good controlled patients $(P<0.001)$. Serum Cu was statistically significantly lower in the poorly controlled patients when compared to the good controlled patients $(P<0.05)$ (Table 3$)$.

The A1c \% had a statistically significant positive correlation with the duration of illness $(P<0.001)$, statistically

Table I Demographics, clinical, and routine laboratory data of the studied groups

\begin{tabular}{|c|c|c|c|c|}
\hline Variables & $\begin{array}{l}\text { Diabetic group } \\
(n=100)\end{array}$ & $\begin{array}{l}\text { Control group } \\
(n=40)\end{array}$ & t-test & $P$-value \\
\hline Age (years), mean $\pm S D$ & $11.6 \pm 2.9$ & $11.4 \pm 2.8$ & 0.2 & 0.80 \\
\hline $\mathrm{BMI}\left(\mathrm{kg} / \mathrm{m}^{2}\right)$, mean $\pm \mathrm{SD}$ & $18.5 \pm 1.7$ & $18.6 \pm 0.7$ & 0.1 & 0.90 \\
\hline Sex: male/female & $50 / 50$ & $18 / 22$ & $\chi^{2 / 0} 0.03$ & 0.80 \\
\hline Total cholesterol (mmol/L) & $4.1 \pm 0.7$ & $3.9 \pm 0.5$ & 0.2 & 0.056 \\
\hline Triglycerides (mmol/L) & $1.2 \pm 0.22$ & $1.2 \pm 0.18$ & 0.22 & 0.066 \\
\hline FPG (mmol/L) & $10.6 \pm 2.5$ & $4.8 \pm 0.8$ & 0.8 & $<0.001 * *$ \\
\hline Duration of illness (years), mean \pm SD & $4.8 \pm 2.6(I-I I)$ & - & & \\
\hline Insulin dose(unit/kg), mean \pm SD & $1.06 \pm 0.2(0.5-1.5)$ & - & & \\
\hline Insulin type & & - & & \\
\hline Premix insulin & 55 (55\%) & & & \\
\hline Basal bolus & $45(45 \%)$ & & & \\
\hline \multicolumn{5}{|l|}{ Daily monitoring by RPG } \\
\hline Once/day & $15(15 \%)$ & - & & \\
\hline Twice/day & 40 (40\%) & & & \\
\hline Three times/day & 45 (45\%) & & & \\
\hline
\end{tabular}

Note: **Highly significant.

Abbreviations: FPG, fasting plasma glucose; RPG, random plasma glucose.

Table 2 Comparison between the diabetic and control groups in the laboratory investigations

\begin{tabular}{|c|c|c|c|c|}
\hline Variables & $\begin{array}{l}\text { Diabetic group } \\
(n=100)\end{array}$ & $\begin{array}{l}\text { Control group } \\
(n=40)\end{array}$ & t-test & $P$-value \\
\hline Alc $\%$ mean \pm SD & $8.6 \pm 2.2(6.5-12.2)$ & $5.1 \pm 0.4(4.5-6.0)$ & 9.3 & $\leq 0.00 I^{* *}$ \\
\hline $\mathrm{Cu}(\mathrm{ug} / \mathrm{dL})$ mean $\pm \mathrm{SD}$ & $74.6 \pm 9.2(68.8-80.7)$ & $166.1 \pm 38.5(160-173.4)$ & 4 & $\leq 0.001 * *$ \\
\hline $\mathrm{Mg}(\mathrm{mg} / \mathrm{dL})$ mean $\pm \mathrm{SD}$ & $1.96 \pm 0.2(1.5-2.5)$ & $2.2 \pm 0.22(1.9-3.5)$ & 2.8 & $\leq 0.05^{*}$ \\
\hline $\mathrm{Zn}(\mathrm{ug} / \mathrm{dlL})$ mean $\pm \mathrm{SD}$ & $103.3 \pm 15.7(94.4-1 \mid 15.6)$ & $129.6 \pm 31.5(\mid 15.6-140.3)$ & 2.00 & $\leq 0.05^{*}$ \\
\hline $\mathrm{Se}(\mathrm{ng} / \mathrm{mL})$ mean $\pm \mathrm{SD}$ & $16.1 \pm 4(7.6-27.7)$ & $33.7 \pm 5.7(22.8-41.05)$ & 9.5 & $\leq 0.00 I^{* *}$ \\
\hline $\mathrm{GSH}(\mathrm{mg} / \mathrm{gHb})$ mean $\pm \mathrm{SD}$ & $1.69 \pm 0.6(0.8-2.8)$ & $2.74 \pm 0.46(2.0-3.6)$ & 7.0 & $<0.00 I^{* *}$ \\
\hline $\mathrm{GPx}(\mathrm{U} / \mathrm{gHb})$ mean $\pm \mathrm{SD}$ & $23.2 \pm 6.4(16.0-38.0)$ & $32.1 \pm 4.4(25.0-41.0)$ & 6.8 & $<0.00 I^{* *}$ \\
\hline
\end{tabular}

Note: *Significant; **Highly significant

Abbreviations: Alc \%; glycosylated hemoglobin; Cu, copper; GPx, glutathione peroxidase; GSH, reduced glutathione; Mg, magnesium, Se, selenium; Zn, zinc. 
Table 3 Comparison between poor- and good-controlled diabetics regarding laboratory investigations

\begin{tabular}{|c|c|c|c|c|}
\hline Variable & $\begin{array}{l}\text { Poor control } \\
(A \mid c \geq 7.5 \%) \\
(n=75)\end{array}$ & $\begin{array}{l}\text { Good control } \\
(A \mid c<7.5 \%) \\
(n=25)\end{array}$ & $t$-test & $P$-value \\
\hline $\mathrm{Cu}(\mathrm{ug} / \mathrm{dL})$ mean $\pm \mathrm{SD}$ & $70.5 \pm 8.2(68.8-78.8)$ & $77.8 \pm 9.2(74.5-80.7)$ & 2.1 & $<0.05^{*}$ \\
\hline $\mathrm{Mg}(\mathrm{mg} / \mathrm{dL})$ mean $\pm \mathrm{SD}$ & $1.88 \pm 0.2(1.5-1.99)$ & $2.03 \pm 0.24(1.7-2.5)$ & 5.9 & $<0.001 * *$ \\
\hline $\mathrm{Zn}(\mathrm{ug} / \mathrm{dL})$ mean $\pm \mathrm{SD}$ & $95.9 \pm 2.4(94.4-98.7)$ & $110.6 \pm 17.7(101.2-115.6)$ & 8.7 & $<0.00 I^{* *}$ \\
\hline $\mathrm{Se}(\mathrm{Ng} / \mathrm{mL})$ mean $\pm \mathrm{SD}$ & $15.6 \pm 6.1(7.6-26.4)$ & $24.7 \pm 6.5(20.5-27.6)$ & 5.1 & $<0.001 * *$ \\
\hline $\mathrm{GSH}(\mathrm{mg} / \mathrm{gHb})$ mean $\pm \mathrm{SD}$ & $1.35 \pm 0.11(0.8-2.0)$ & $2.5 \pm 0.23(2.4-2.8)$ & 6.8 & $<0.00 I^{* *}$ \\
\hline $\mathrm{GPx}(\mathrm{U} / \mathrm{gHb})$ mean $\pm \mathrm{SD}$ & $20.0 \pm 3.8(16.0-30.1)$ & $31.7 \pm 4.6(26.5-38)$ & 6.4 & $<0.00 I^{* *}$ \\
\hline
\end{tabular}

Note: *Significant; **Highly significant

Abbreviations: Alc \%, glycosylated hemoglobin; Cu, copper; GPx, glutathione peroxidase; GSH, reduced glutathione; Mg, magnesium, Se, selenium; Zn, zinc.

Table 4 Correlation between duration of illness, insulin dose and Alc \% with other parameters of the diabetic group

\begin{tabular}{|c|c|c|c|c|c|c|}
\hline \multirow[t]{2}{*}{ Variables } & \multicolumn{2}{|c|}{ Duration of illness } & \multicolumn{2}{|c|}{ Insulin dose } & \multicolumn{2}{|l|}{ Alc \% } \\
\hline & $r$ & $P$ & $r$ & $P$ & $r$ & $P$ \\
\hline Age & 0.4 & $>0.05$ & 0.5 & $<0.05^{*}$ & 0.3 & $>0.05$ \\
\hline BMI\% & 0.03 & $>0.05$ & 0.1 & $>0.05$ & 0.1 & $>0.05$ \\
\hline Insulin dose & 0.3 & 0.05 & - & - & 0.3 & $>0.05$ \\
\hline Duration of illness & - & - & 0.3 & $>0.05$ & 0.7 & $<0.00 I^{* *}$ \\
\hline Alc \% & 0.7 & $<0.00 I^{* *}$ & 0.3 & $>0.05$ & - & - \\
\hline $\mathrm{Cu}$ & -0.05 & $>0.05$ & 0.1 & $>0.05$ & -0.07 & $>0.05$ \\
\hline $\mathrm{Mg}$ & -0.6 & $<0.05^{*}$ & -0.1 & $>0.05$ & -0.6 & $<0.001^{* *}$ \\
\hline $\mathrm{Zn}$ & -0.2 & $<0.05^{*}$ & -0.07 & $>0.05$ & -0.5 & $<0.05^{*}$ \\
\hline $\mathrm{Se}$ & -0.80 & $<0.00 I^{* *}$ & -0.3 & $>0.05$ & -0.4 & $<0.05^{*}$ \\
\hline GSH & -0.7 & $<0.00 I^{* *}$ & 0.2 & $>0.05$ & -0.7 & $<0.00 I^{* *}$ \\
\hline GPx & -0.7 & $<0.00 I^{* *}$ & 0.2 & $>0.05$ & -0.7 & $<0.00 I^{* *}$ \\
\hline
\end{tabular}

Note: *Significant; **Highly significant

Abbreviations: Alc \%, glycosylated hemoglobin; Cu, copper; GPx, glutathione peroxidase; GSH, reduced glutathione; Mg, magnesium, Se, selenium; Zn, zinc.

significant negative correlation with $\mathrm{Se}, \mathrm{Zn}, \mathrm{Mg}, \mathrm{GSH}$, and $\operatorname{GPx}(P<0.05)$ and no statistically significant correlation with age, $\mathrm{BMI}, \mathrm{Cu}$, and insulin dose $(P>0.05)$.

The duration of illness showed a statistically significant positive correlation with the A1c \% $(P<0.001)$, statistically significant negative correlation with $\mathrm{Se}, \mathrm{Zn}, \mathrm{Mg}, \mathrm{GSH}$, and GPx and no statistically significant correlation with age, BMI, $\mathrm{Cu}$, and insulin dose $(P>0.05)$.

The insulin dose showed a statistically significant positive correlation with age $(P<0.05)$ and no statistically significant correlation with duration of illness, $\mathrm{A} 1 \mathrm{c} \%, \mathrm{Se}, \mathrm{Zn}, \mathrm{Mg}$ and $\mathrm{Cu}(P<0.05)$ (Table 4$)$. The serum Se had a statistically significant positive correlation with both erythrocyte GSH and GPx ([r=0.56, $P<0.001][\mathrm{r}=0.78, P<0.001]$, respectively) (Figure 1). Scatter plots between A1c \% and the corresponding measurement of serum $\mathrm{Se}, \mathrm{Cu}, \mathrm{Zu}, \mathrm{Mg}$, erythrocyte $\mathrm{GSH}$, and GPx are shown in Figure 2.

\section{Discussion}

Our study showed that the serum $\mathrm{Se}, \mathrm{Zn}, \mathrm{Mg}$, and $\mathrm{Cu}$ were significantly lower in the diabetic group in comparison to the control group as shown in Table 2. This agrees with Özenç et al who found lower serum Se and $\mathrm{Zn}$ and normal serum $\mathrm{Cu}$ levels in children with T1D in comparison to controls. They explained the low serum Se level in patients with T1D might be due to its consumption by the increased activity of the antioxidant GSH-GPx system in order to reduce the free radicals produced by increased oxidative stress. ${ }^{1}$

Also, Maher and Shaaban reported lower serum Mg, Zn, and $\mathrm{Cu}$ in diabetic children than in controls. ${ }^{14}$ The decrease in $\mathrm{Mg}$ may be explained by the increased urinary $\mathrm{Mg}$ excretion, $\mathrm{Mg}$ conservation in the loop of Henle and distal tubule by insulin, inadequate $\mathrm{Mg}$ intake or gastrointestinal disorders. ${ }^{15}$ The low serum $\mathrm{Cu}$ in T1D may be secondary to excessive loss of $\mathrm{Cu}$ in the urine. ${ }^{16}$

Another study was done by Salmonowicz et al, which compared diabetic children to their sibling and to a control group. They found comparable levels of serum Se between all groups and lower levels of serum $\mathrm{Mg}$ and $\mathrm{Zn}$ and higher serum $\mathrm{Cu}$ in children with T1D compared with the control and sibling groups. ${ }^{17}$ The lower serum zinc in T1D cases is 


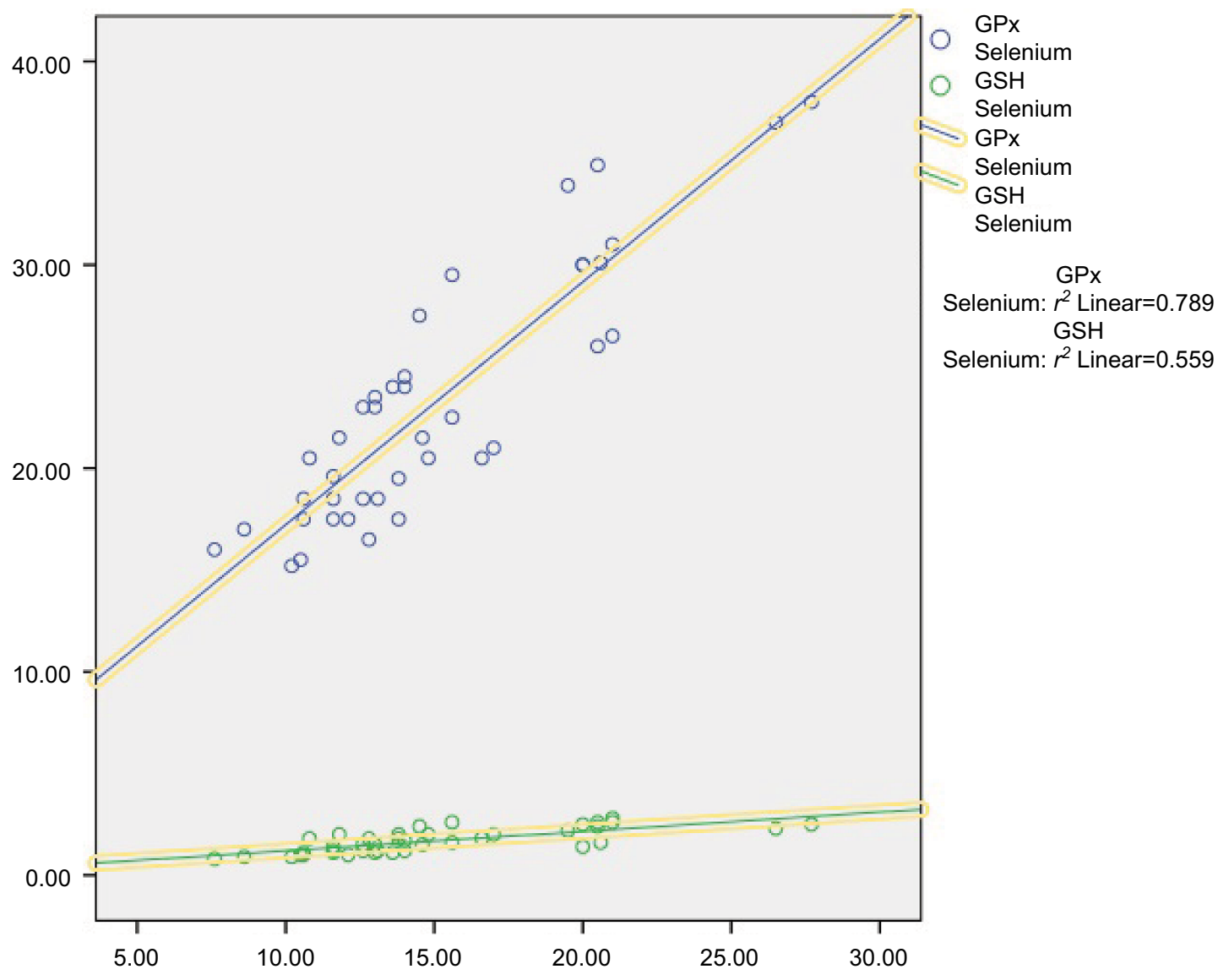

Figure I A correlation study between serum Se level and erythrocyte GSH and GPx. Abbreviations: GPx, glutathione peroxidase; GSH, reduced glutathione.

probably due to diabetes-related hyper zin-curia and impaired intestinal absorption of zinc. ${ }^{14}$

However, Zargar et al found higher serum Zn level and normal serum $\mathrm{Cu}$ and $\mathrm{Mg}$ levels in T1D. ${ }^{18}$ Another large study done in diabetic adults found increased serum Se, $\mathrm{Zn}$, and $\mathrm{Cu}$ and decreased serum $\mathrm{Mg}$ in diabetic patients than in controls. ${ }^{19}$ Other studies reported either lower levels of serum $\mathrm{Mg}$ and normal $\mathrm{Zn},{ }^{20}$ or lower serum $\mathrm{Zn}$ and increased serum $\mathrm{Cu}$ levels, ${ }^{21}$ or normal serum $\mathrm{Zn}{ }^{22}$ in T1D in comparison to controls.

The variability of the results in the levels of trace elements in different studies may be due to the differences in the sample sizes, the age of patients, the surrounding environment, duration of the disease, ethnicity, nutritional habits and status, and glycemic control of the patients under the study.

Oxidative stress parameters (erythrocyte GSH and GPx) in our study showed a significant difference between diabetic and control groups being lower in the diabetic group as shown in Table 2. Previous studies found a low level of GSH either in the plasma or in the erythrocytes both in children and adults. ${ }^{23-25}$ The low erythrocyte GSH may be due to extensive oxidative stress with over-consumption of $\mathrm{GSH},{ }^{25}$ or secondary to the sluggish production of NADPH by the pentose phosphate pathway which is stimulated by insulin, thus lowering GSH activity and reduced GSH recycle. ${ }^{26}$

Studies done on serum or erythrocyte GPx activities in diabetics were variables, either increased or decreased or normal GPx activity was reported in children with T1D. ${ }^{23,27-30}$ The decreased GPx activity may be due to low glutathione content or enzyme inactivation under severe oxidative stress. ${ }^{24,31}$

The diabetic group was classified into two groups according to A1c \% (7.5\%). Diabetic children were considered poorly controlled if A $1 \mathrm{c} \%$ was $\geq 7.5 \%$. We found a statistically significant difference between poor and good controlled groups in $\mathrm{Mg}, \mathrm{Zn}, \mathrm{Se}, \mathrm{Cu}$, erythrocyte $\mathrm{GSH}$, and GPx being lower in the poorly controlled group as shown in Table 3 . This is in agreement with previous different studies that found the same results, but with higher A1c \% ( $\geq 9 \%)$ as a cutoff value for the poor control of diabetic children in their studies and on variable trace elements. ${ }^{7,14.15}$ The results of our study usually occurred due to the poor glycemic control of most our patients evidenced by higher mean A1c \% level (8.6 \pm 2.2$)$ than optimum A1c \% (less than 7.5\%) for good control of diabetic children, $75 \%$ of the patients had A1c $\%>7.5 \%$ 


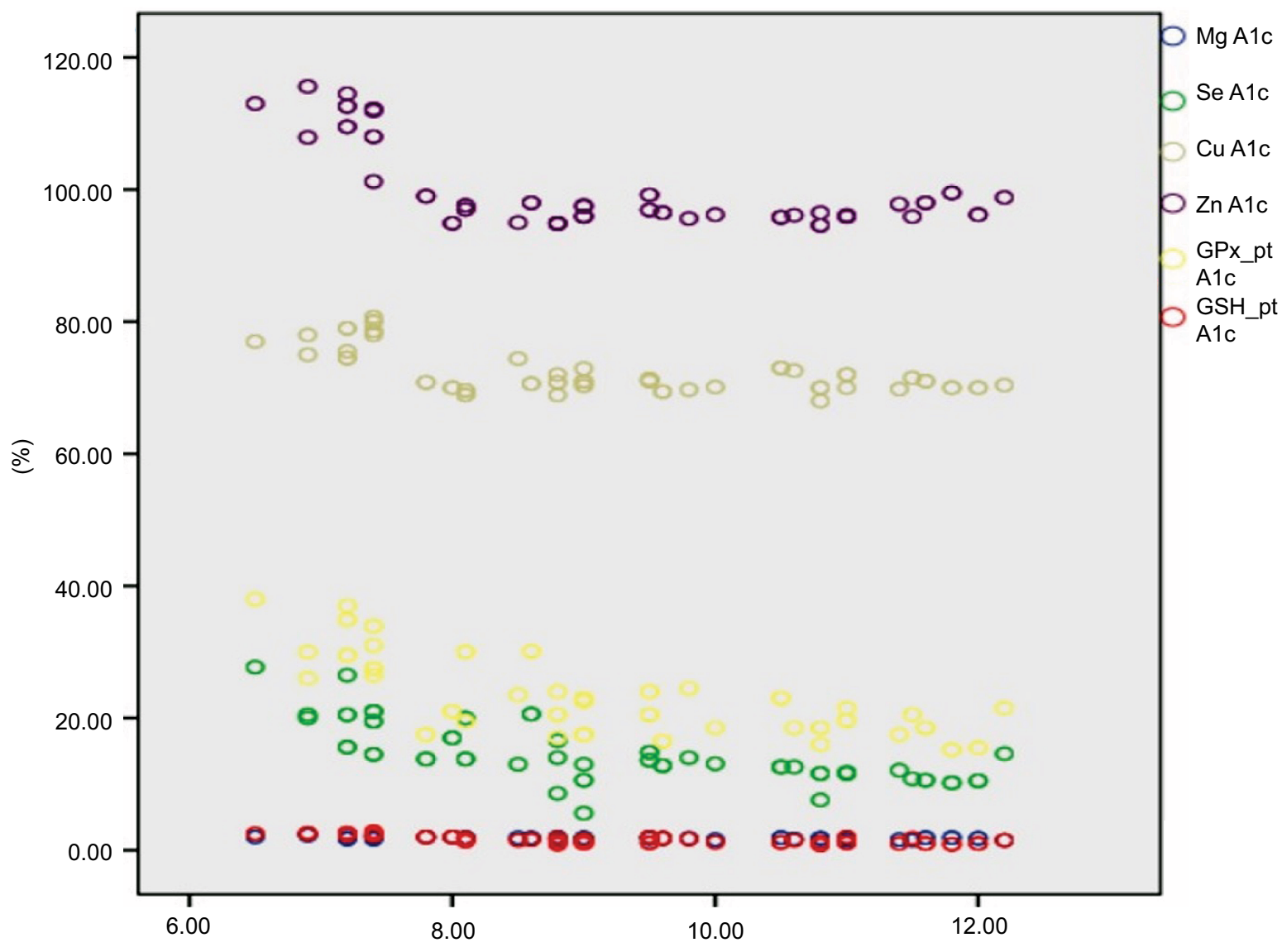

(\%)

Figure 2 Scatter plots between Alc \% and corresponding measurement serum Se, Cu, Zu, Mg, and erythrocyte GSH and GPx.

Abbreviations: Alc \%, glycosylated hemoglobin; $\mathrm{Cu}$, copper; GPx, glutathione peroxidase; GSH, reduced glutathione; HbAlc, hemoglobin Alc; Mg, magnesium, Se, selenium, Zn, zinc.

and higher mean FPS $(10.6 \pm 2.5) \mathrm{mmol} / \mathrm{L}$. The presence of comparable BMI between patients and controls and average nutritional history somewhat excludes the nutrition status as the main cause for low levels of trace elements in our study.

In the current study, we found that there was a significant negative correlation between $\mathrm{A} 1 \mathrm{c} \%$ and serum $\mathrm{Mg}, \mathrm{Zn}, \mathrm{Se}$, erythrocyte GSH, and GPx, and no statistically significant correlation with age, BMI and $\mathrm{Cu}$ in the case group as shown in Table 4. This agrees with Özenç et al who found a negative correlation between the A1c \% with serum Se, $\mathrm{Zn}$, and erythrocyte GPx and no correlation was detected between $\mathrm{A} 1 \mathrm{c} \%$ and serum $\mathrm{Cu} .{ }^{1}$ Also, Maher and Shaaban found that serum $\mathrm{Zn}, \mathrm{Mg}$, and $\mathrm{Cu}$ levels were negatively correlated with A1c \% ${ }^{14}$ Another study found a negative correlation between GSH with FPG and no correlation between GPx with FPG. ${ }^{23}$

Other studies found a negative correlation between A1c $\%$ with $\mathrm{Mg}^{15}$ and between A1c \% with Se. ${ }^{7}$ However, Salmonowicz et al. revealed a positive correlation between A1c $\%$ and serum $\mathrm{Mg}, \mathrm{Cu}$, and $\mathrm{Zn}$; with a tendency to statistical significance with $\mathrm{Se}(P=0.06) .{ }^{17}$ Other studies found no cor- relations between $\mathrm{A} 1 \mathrm{c} \%$ and serum $\mathrm{Zn}$ and $\mathrm{Cu}^{20}$ or between $\mathrm{A} 1 \mathrm{c} \%$ and serum $\mathrm{Zn} .{ }^{22}$

The duration of illness showed a significant positive correlation with A1c \% $(P=0.001)$, a significant negative correlation with serum $\mathrm{Se}, \mathrm{Zn}, \mathrm{Mg}$, erythrocyte GSH, and GPx and no significant correlation with serum $\mathrm{Cu}$, age, $\mathrm{BMI}$, and insulin dose as shown in Table 4. In accordance with Maher and Shaaban study who found the same results regarding serum $\mathrm{Mg}, \mathrm{Zn}$, and $\mathrm{Cu}$. They explained the low $\mathrm{Cu}$ level with prolonged diabetes duration may be due to $\mathrm{Cu}$ consumption in the oxidation-reduction reactions because it acts as cofactors for cytochrome oxidase and superoxide dismutase. ${ }^{14}$ Insulin deficiency and resistance can affect tubular reabsorption of $\mathrm{Mg}$ and this explains negative correlation between $\mathrm{Mg}$ level and diabetes duration..$^{32}$ Other studies found no correlation between diabetes duration with serum $\mathrm{Se}, \mathrm{Zn}$, or Mg. ${ }^{6,20,22}$

In the diabetic group, we found that there was a significant positive correlation between insulin dose and age $(P=0.01)$. This agrees with Lin et al's study which found that T1D children needed to increase the insulin dose with the increase of the age of the child. ${ }^{21}$ 
In our study, the serum Se showed a significant positive correlation with the erythrocyte levels of GSH and GPx denoting that low Se level affects the GSH-GPx system levels and function by altering its role in protecting the cell membrane against oxidants. This occurs as Se enters into the structure of the GSH-GPx system. ${ }^{5}$ Sedighi et al found low Se and GPx levels in adults with diabetic nephropathy and both were correlated with the degree of albuminuria. ${ }^{33}$

\section{Conclusion}

Children with T1D especially poorly controlled, had low serum $\mathrm{Se}, \mathrm{Zn}, \mathrm{Mg}, \mathrm{Cu}$, erythrocyte GSH, and GPx. The low serum Se in diabetic children may play an important role in the dysfunction of the GSH-GPx system. We recommend for good glycemic control, follow-up of serum trace elements in diabetic children and more studies on other trace elements and their relation to indicators of oxidative stress.

\section{Disclosure}

The authors report no conflicts of interest in this work.

\section{References}

1. Özenç S, Saldir M, Sarı E, et al. Selenium, zinc, and copper levels and their relation with $\mathrm{HbA} 1 \mathrm{c}$ status in children with type 1 diabetes mellitus. Int J Diabet Dev Countries. 2015;35(4):514-518.

2. Viktorínová A, Toserová E, Krizko M, Duracková Z. Altered metabolism of copper, zinc, and magnesium are associated with increased levels of glycated hemoglobin in patients with diabetes mellitus. Metabolism. 2009;58(10):1477-1482.

3. Praveeena S, Pasula S, Sameera K. Trace elements in diabetes mellitus. J Clin Diagn Res. 2013;7(9):1863-1865.

4. Laclaustra M, Stranges S, Navas-Acien A, Ordovas JN, Guallar E. Serum selenium and serum lipid in U.S Adult: national health and nutrition examination survey (NHANES) 2003-2004. Atherosclerosis. 2010;2010(2):643-648.

5. Rayman MP. The importance of selenium to human health. Lancet. 2000;356(9225):233-241.

6. Forte G, Bocca B, Peruzzi A, et al. Blood metals concentration in type 1 and type 2 diabetics. Biol Trace Elem Res. 2013;156(1-3):79-90.

7. Ruiz C, Alegria A, Barberá R, Farré R, Lagarda J. Selenium, zinc, and copper in plasma of patients with type 1 diabetes mellitus in different metabolic control states. J Trace Elem Med Biol. 1998;12(2):91-95.

8. Gardiner PHE, Littlejohn D, Halls DJ, Fell GS. Direct determination of selenium in human blood serum and plasma by electrothermal atomic absorption spectrometry. Trace Elem Med Biol J. 1995;9(2):74-81.

9. Johnsen O, Eliasson R. Evaluation of a commercially available kit for the colorimetric determination of zinc. Int J Androl. 1987;10(2) $435-440$

10. Abe A, Yamashita S, Noma A. Sensitive, direct colorimetric assay for copper in serum. Clin Chem. 1989;35(4):552-554.

11. Ginder EM, Heth DA. Colorimeter determination with bound "Calmagite" of magnesium in human blood serum. Clin Chem. 1971; 17:662.

12. Paglia DE, Valentine WN. Studies on the quantitative and qualitative characterization of erythrocyte glutathione peroxidase. J Lab Clin Med. 1967;70:158-169.
13. Beutler E, Duron O, Kelly BM. The improved method for the determination of blood glutathione. J Lab Clin Med. 1963;61:882-888.

14. Ahmed MM, Helal SR. Study of serum magnesium, zinc, copper, and glyco-hemoglobin in children with type 1 diabetes mellitus. Alexandria J Ped. 2002;16(2):285-289.

15. Galli-Tsinopoulou A, Maggana I, Kyrgios I, et al. Association between magnesium concentration and $\mathrm{HbA} 1 \mathrm{c}$ in children and adolescents with type 1 diabetes mellitus. J Diabetes. 2014;6(4):369-377.

16. Zheng, Y, Li, XK, Wang, Y, Cai L. The role of zinc, copper, and iron in the pathogenesis of diabetes and diabetic complications: therapeutic effects by chelators. Hemoglobin. 2008;32(1-2):135-145.

17. Salmonowicz B, Krzystek KM, Noczyńska A. Trace elements, magnesium and the efficacy of antioxidant systems in children with type 1 diabetes mellitus and in their siblings. Adv Clin Exp Med. 2014;23(2):259-268.

18. Zargar, AH, Bashir, MI., Masoodi, SR, et al. Copper, zinc and magnesium levels in type-1 diabetes mellitus. Saudi Med J. 2002;23(5): 539-542.

19. Zanagh $H$, Yan C, Yang Z, et al. Alterations of serum trace elements in patients with type 2 diabetes. J Trace Elem Med Biol. 2017;40:91-96.

20. Lin CC, Tseng GJ, Lee CF, Chen BH, Huang YL. Magnesium, zinc, and chromium levels in children, adolescents, and young adults with type 1 diabetes. Clin Nutr. 2016;35(4):880-884.

21. Lin CC, Huang $\mathrm{HH}, \mathrm{Hu} \mathrm{CW}$, et al. Trace elements, oxidative stress and glycemic control in young people with type 1 diabetes mellitus. J Trace Elem Med Biol. 2014;28(1):18-22.

22. Estakhri M, Djazayery A, Eshraghian M, et al. Serum zinc levels in children and adolescents with type-1 diabetes mellitus. Iran J Public Health. 2011;40(4):83-88.

23. Likidilid A, Patchanans N, Poldee S, Peerapatdit T. Glutathione and glutathione peroxidase in type 1 diabetes mellitus. J Med Assoc Thai. 2007;90(9):1759-1767.

24. Mishra N, Singh N. Blood viscosity, lipid profile, lipid peroxidation in type-1 diabetic patients with good and poor glycemic control. NAm J Med Sci. 2013;5(9):562-566.

25. Stambouli-Guerriche BA, Mokhtari-Soulimane N, Merzouk H, Merzouk S-A, Bendedouche SA. Elevation of oxidative stress markers in type 1 diabetic children. J Diabetes Endocrinol. 2015;6(2):5-11.

26. Wierusz-Wysocka B, Wysocki H, Byks H, Zozulińska D, Wykretowicz A, Kaźmierczak M. Metabolic control quality and free radical activity in diabetic patients. Diabetes Res Clin Pract. 1995;27(3):193-197.

27. Ndahimana J, Dorchy H, Vertongen F. Erythrocyte and plasma antioxidant activity in diabetes mellitus type 1. Presse Méd. 1996;25(5): 188-192.

28. Ezeiruaku FC, Udenwoke IO. Evaluation of plasma glutathione peroxidase (GPX) enzyme in type 1 and type 2 chronic diabetes mellitus patients in Yenegoa, Bayelsa State of Nigeria. Int Res Med Sci. 2016;4(3):050-054.

29. Domínguez C, Ruiz E, Gussinye M, Carroscosa A. Oxidative stress at onset and in early stages of type 1 diabetes in children and adolescents. Diabetes Care. 1998;21(10):1736-1742.

30. Majchrzak, A, Zozulińska, D, Wierusz-Wysocka, WB. Evaluation of selected components in antioxidant systems of blood in patients with diabetes. Pol Merkur Lekarski. 2001;10(57):150-152.[Article in Polish]

31. Faure P, Benhamou, PY, Perard, A, Halimi S, Roussel AM. Lipid peroxidation in insulin-dependent diabetic patients with early retina degenerative lesions: effects of an oral zinc supplementation. Eur $J$ Clin Nutr. 1995;49:282-288.

32. Arpaci D, Tocoglu, A, Ergenc H, Korkmaz S, Acar A, Tamer A. Associations of serum magnesium levels with diabetes mellitus and diabetic complications. Hippokratia. 2015;19(2):153-157.

33. Sedighi O, Makhlough A, Shokrzadeh M, Hoorshad S. Association between plasma selenium and glutathione peroxidase levels and severity of diabetic nephropathy in patients with type two diabetes mellitus. Nephrourol Mon. 2014;6(5):e21355. 
Diabetes, Metabolic Syndrome and Obesity: Targets and Therapy is an international, peer-reviewed open-access journal committed to the rapid publication of the latest laboratory and clinical findings in the fields of diabetes, metabolic syndrome and obesity research. Original research, review, case reports, hypothesis formation, expert opinion and commentaries are all considered for publication. The manuscript management system is completely online and includes a very quick and fair peer-review system, which is all easy to use. Visit http://www.dovepress.com/testimonials.php to read real quotes from published authors.

Submit your manuscript here: https://www.dovepress.com/diabetes-metabolic-syndrome-and-obesity-targets-and-therapy-journal 